\title{
Midwest Health Services: Purchasing Patient Snacks
}

Timothy Moffit, Kalamazoo College, USA

Michelle Gigowski, USA

\begin{abstract}
Melanie Griffin is a recent college graduate who has been asked by her supervisor to evaluate the consumption of snacks and pop at the ambulatory surgery center for which she works. Immediately, Melanie is confronted with the cultural complexities of a small health services operation. The reader discovers these complexities through a lively meeting dialogue, and the reader is then asked to help Melanie prepare for a follow-up meeting by identifying, analyzing, and preparing possible procurement solutions. The richness of this case is attributed to the practical quantitative consumption and pricing analysis coupled with the complexities of implementation because of the array of personalities. This case is appropriate for early undergraduate courses in management, marketing, and managerial accounting.
\end{abstract}

Keywords: Leadership; Purchasing; Customer Satisfaction; Business Case Study

\section{INTRODUCTION}

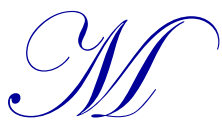

elanie Griffin sat in the nurses' office late Monday afternoon, contemplating the possible outcomes of a purchasing meeting to be held Tuesday morning. Having graduated just three months prior with a biology and business major from a Michigan liberal arts college, she was hired by Midwest Health Services (MHS) to improve the purchasing and inventory processes at the company's ambulatory surgery center (ASC). She soon realized how easy the classroom problems seemed relative to the real world problems of business and health care.

From previous discussions Melanie has had with the ASC staff (see Table I), she knows that Tuesday's meeting is going to be a lively meeting with lots of personality and "turf" issues. But to Melanie, it all seemed quite silly given the decision at hand was merely a pop and snacks purchasing decision. Her supervisor, Sally Sopjes, assured her that this is an important decision to staff, patient and physician morale. So, the decision must be developed and implemented carefully. Otherwise, in Sally's words, "we could have a revolt on our hands".

Table I: Midwest Health Services ASC Personnel

\begin{tabular}{|l|l|l|c|c|}
\hline \multicolumn{1}{|c|}{ Name } & \multicolumn{1}{|c|}{ Position } & \multicolumn{1}{c|}{ Work Schedule } & $\begin{array}{c}\text { Duration of } \\
\text { Employment }\end{array}$ & Age \\
\hline Martha Crooks & Reprocessing & Full - Time & 25 years & 63 \\
\hline Jenny Alexandar & Front Desk & Full - Time & 2 years & 46 \\
\hline Karley Smithson & Post-Op Nurse & Part - Time & 8 years & 26 \\
\hline Melanie Griffin & Materials Coordinator & Full - Time & $<1$ years & 22 \\
\hline Sally Sopjes & Director of ASC & Salaried & 27 years & 62 \\
\hline
\end{tabular}

Melanie was trying to figure out the impact, if any, the purchasing decision would have on patient flow (see Figure I). Also, she was curious where Sally stood on this decision. During the lunch break earlier in the day, Melanie approached Sally about the meeting agenda and Sally's position, as the ASC Director, on the snack purchasing decision. Sally told her, "I don't know. You are the whiz kid they hired to clean up purchasing." 


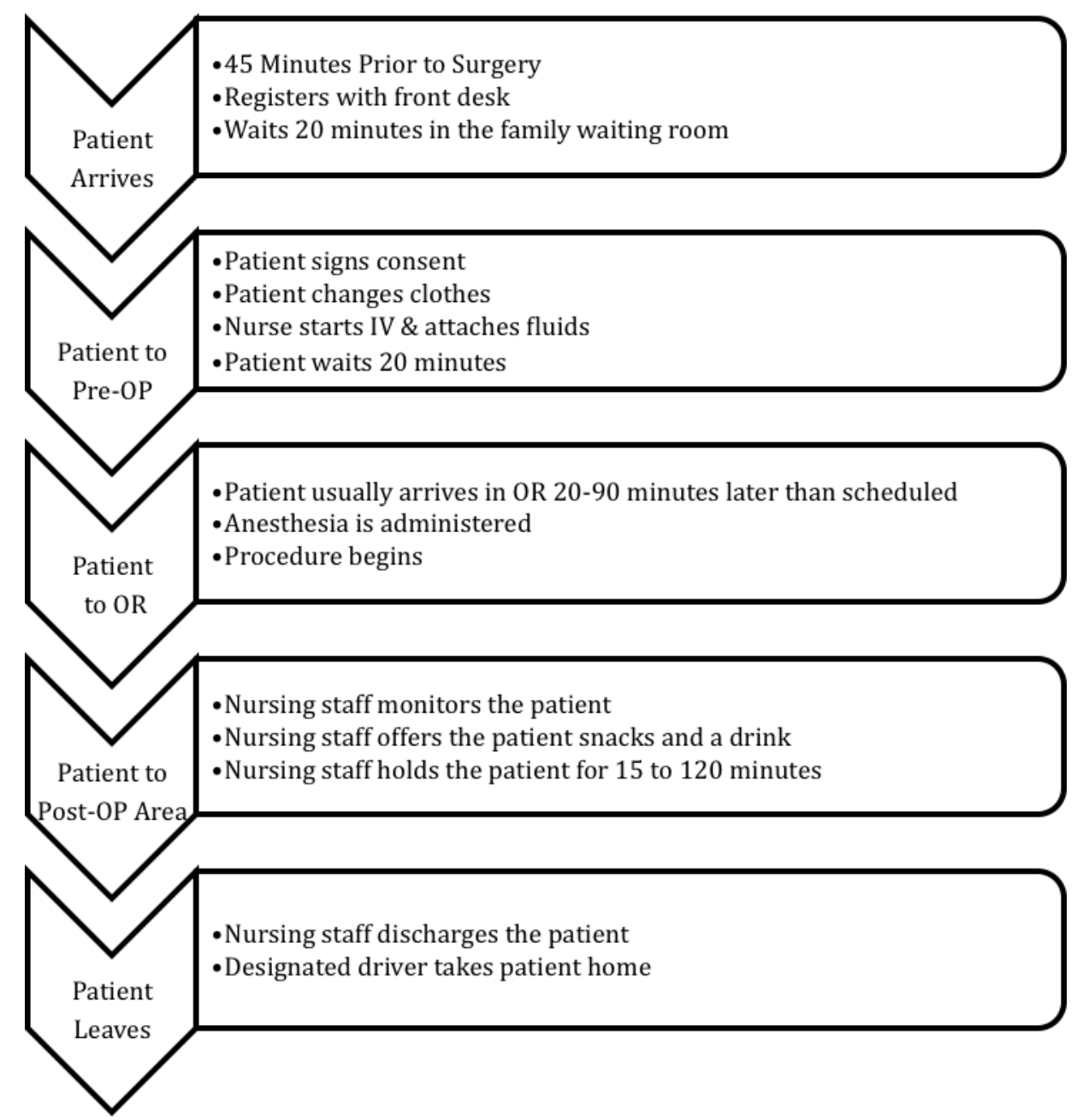

Figure I: ASC Patient Flow

\section{BACKGROUND}

After the acquisition of two endoscopy physicians by Midwest Health Services in 1997, the two-room endoscopy facility, built in 1989, had been rebuilt into a four-operating-room, multispecialty ASC. Current ASC case volume is generated by ear, nose and throat, endoscopy, hand, orthopedic, urology, and general surgery physicians (see Tables II and III).

Table II: Case Volume by Specialty

\begin{tabular}{|l|c|c|}
\hline \multicolumn{1}{|c|}{ Procedure Type } & Practicing Physicians & Annual Case Volume \\
\hline Ear, Nose \& Throat & 4 & 1,267 \\
\hline Endoscopy & 3 & 634 \\
\hline General Surgery & 6 & 1,382 \\
\hline Hand & 5 & 749 \\
\hline Orthopedic & 7 & 922 \\
\hline Urology & 9 & 5,760 \\
\hline Total & 34 & \\
\hline
\end{tabular}


Table III: Top 15 Referring Physicians by Case Volume*

\begin{tabular}{|l|l|c|}
\hline \multicolumn{1}{|c|}{ Physician } & \multicolumn{1}{|c|}{ Procedure Type } & Annual Case Volume \\
\hline Dr. Dasha & Ear, Nose \& Throat & 635 \\
\hline Dr. Manther & Hand & 461 \\
\hline Dr. Jakward & Hand & 454 \\
\hline Dr. Heap & Endoscopy & 404 \\
\hline Dr. Lowdome & Orthopedic & 336 \\
\hline Dr. Zeppelin & Urology & 318 \\
\hline Dr. Prince & Hand & 279 \\
\hline Dr. Stevens & Ear, Nose \& Throat & 269 \\
\hline Dr. Meish & General Surgery & 254 \\
\hline Dr. Rhodes & Urology & 241 \\
\hline Dr. Demasiado & Ear, Nose \& Throat & 230 \\
\hline Dr. Payne & General Surgery & 221 \\
\hline Dr. Stevia & Orthopedic & 198 \\
\hline Dr. Oculus & Urology & 182 \\
\hline Dr. Lamb & Orthopedic & 125 \\
\hline$*$ These data account for about 80\% of total cases preformed at the ASC & \\
\hline
\end{tabular}

\section{PERSONNEL}

\section{Sally Sopjes, R.N., Director (age 62).}

Prior to being appointed the ASC Director three years ago, Sally worked in various clinical roles at the facility for the past 22 years. Her most recent role was charge nurse. By Sally's own admission, she is currently a little "rusty" on clinical techniques. Sally has had no formal training in business or management. She was moved into management positions over the years because, in her words, she is a "problem solver". As the Director of the largest MHS ancillary, Sally reports directly to the CEO. In her latest annual review, she was given an "average" rating. In the performance notes, the $\mathrm{CEO}$ wrote, “...has problems listening, executing instructions, prioritizing, and developing a team culture". Sally objected to this part of her review, writing the following rebuttal remarks. "I am a fiercely loyal employee who works extremely hard. My experience is unmatchable at the ASC and within the company.”

\section{Martha Crooks, L.P.N., Operative Support, (age 63).}

Martha, who began working at this ASC facility 27 years ago, likes to say she has “... worked here since the beginning of time and knows where all of the skeletons are hidden". Her roles at the ASC have included both administrative (materials management and purchasing) and clinical (pre-operative, operative and post-operative) responsibilities. She now serves in a "float" function in the operative suite where she is responsible for reprocessing tools and equipment, preparing the materials for surgical cases, and supporting the nursing staff during cases. Because she was responsible for purchasing until three months ago, she is also charged with helping Melanie learn the purchasing and inventory management functions. The ASC director gave Martha an "excellent" rating during her latest annual review. The company CEO has noted separately that her attitude was defensive and uncooperative in regard to improving purchasing over the years, but that it has improved over the last several months. Five months ago, Martha and her husband purchased a second retirement lake home. She now owns two homes side-by-side, which give her extra space for her family. She speaks regularly about retiring to the lake as soon as her mortgage note on the lake home is paid. Sally and her husband, Terry, regularly spend time during the summer at the lake with Martha and her husband, Larry.

\section{Jenny Alexandar, Clerical Support (age 42).}

Jenny began working for MHS two years ago. She was hired directly into the ASC to provide front desk support. Her primary responsibility has been to prepare charts for the next day's surgery and to verify completeness and accuracy of charts for cases that were performed the previous day. She is also to provide backup to the front desk receptionist when the receptionist is on the phone or with a patient at the counter. About six months ago, her 
hours were extended from 32 to 40 hours per week to take on additional responsibilities, specifically including office supplies purchasing, building maintenance oversight, and scheduling backup. The extra responsibilities and hours became available and were eagerly accepted by Jenny after central administration services (CAS) terminated the clerical manager position for lack of sufficient work responsibilities. Two months after taking on these additional responsibilities, Jenny approached CAS for a pay raise and a pay grade increase because, in her words, "she was now doing the work of a clerical manager". The request was immediately declined by management. Jenny's educational background includes a high school general education diploma (GED) which she earned seven years after dropping out of high school during her sophomore year. Jenny's latest annual employment review was "average". The Director's notes included, "inappropriate time clock entries...insubordination to management directives... misuse of cell phone and internet during company hours...needs work as a team player".

\section{Karley Smithson, R.N., Post-Operative Nurse Leader (age 36).}

Although she works three days each week ( 24 hours), Karley has earned the respect of CAS over the past eight years to function as the post-operative nurse leader. Karley's work is characterized by energy, attention to detail, problem solving, and team play. Karley is liked by most of the staff at the ASC. She is always willing to go the extra mile when working with others. Karley has championed a number of small changes recently in the postoperative area, and these changes have made a significant impact on staff morale and patient satisfaction. In her latest performance review, Karley received an "average" rating by the ASC Director. Two months later, CAS awarded Karly the company's Excellence in Service award for outstanding contribution to company operations and patient quality of care.

\section{Melanie Griffin, Purchasing and Inventory Specialist, (age 23).}

During her senior year in college, Melanie worked as an intern at the ASC to gain practical business experience. After making a cost reduction presentation to the ASC Committee of the MHS Board of Directors, the $\mathrm{CEO}$, at the encouragement of several physicians, hired Melanie immediately upon graduation from a local liberal arts college. Only three months into the job, Melanie developed the analysis, identified the suppliers, and began executing a materials management program that will save the ASC over $\$ 250,000$ annually. Over the next three months, Melanie plans to implement an inventory control system that is estimated to reduce physical inventory by 30 percent and inventory dollars on the shelves by over $\$ 75,000$. The ASC Committee of physicians and the CEO have also directed Melanie to look at all other expense items and identify potential for significant cost reduction. Melanie received an "average" rating at her 90-day review by the ASC Director, but was awarded a 3\% of salary bonus for her excellent work. The CEO instructed Sally last week to hand over management of front desk operations to Melanie.

\section{PURCHASING MEETING}

At 10:00am on Tuesday morning, Jenny, Karley, Melanie, Martha, and Sally, came together to discuss the ASC snacks purchasing process. Melanie began the meeting:

Melanie

Ladies, thank you for taking the time to meet with me this morning. As you know, we must get the snacks purchasing schedule figured out soon. We are somewhat in limbo in terms of the process for purchasing snacks. About a month ago, we made some changes to test some of my preliminary ideas to save money in purchasing snacks. From the trial run, I have some information that may help bring finality to this decision.

Sally, I've done some research and decided that Sam's Club is the most competitively priced snack outlet in our area. Karley and I worked together last month and gathered snacks consumption data. I'm thinking about half the snacks were consumed in the family waiting room, and the other half were used in the postoperation recovery area. I haven't crunched all the numbers yet, but I do know that the majority of Sam's Club's items are cheaper than those purchased at Norman Foods. 
Sally

Martha, you have had extensive experience in purchasing. What do you think of Melanie's ideas?

Martha

Honestly, Sally, I really don't understand why this is even an issue. Jenny has purchased snacks for the past two years from Norman Foods without a hiccup. I just don't see what all the fuss is about.

Sally

You read my mind, Martha. This does seem like a lot of hoopla over a very small issue.

Melanie

But there are real costs savings to be realized here! And CAS just re-emphasized its cost savings objectives for the company.

Sally

If CAS only had a clue...ok, Melanie, how much will we be saving from your ideas?

Melanie

Well, I haven't finished crunching the numb...

Jenny

Wait a second! You mean to tell me we are going to switch snack distributors that easily? I'm still not okay with the switch from Pepsi cans to the Coca Cola fountain drinks.

Sally

Jenny, you know corporate is breathing down my neck about our expenses. We have to save money wherever we can.

Jenny

No, Sally. We need the cans of Pepsi back. Currently, all we have for patients' families in the waiting room are tea and coffee. Every day I have people in the waiting room requesting other beverages. I have too much to do as it is; we front desk girls don't need patients and their families pestering us with beverage requests! It's a good thing we at least have snack foods out in the waiting room to keep the patients' families somewhat happy.

Karley

Jenny, you need to understand how appreciated the Coca Cola fountain pop machine is to everyone in the post-operative recovery area. Once patients get wheeled out of surgery, we are so rushed to get them what they need, make sure everything is alright with the surgery, and get them on their way. We don't have time to deal with the cans and running out to the fridge. The fountain pop machine is a valuable resource for our nursing staff. 
Sally

Plus, Dr. Prince must have his Coke Zero. He fills his mug every time he visits the center. Remember, we must keep our physicians happy!

Melanie

Yes, I agree ladies. We most definitely shouldn't go back to cans of pop. If the nursing staff in the recovery waiting room thinks the cans are a pain, try returning over 1,000 cans to the store by yourself (Michigan has a can deposit of $\$ 0.10$ per can) -- and on your lunch break at that! They hardly even fit into my car. And we were able to free up the back closet for storage once I cleaned out all of the cans that were stashed back there. They're horrible! Jenny. If you want the cans back, you can return the empties yourself.

Sally

Now Melanie, please don't pass out orders like this. Did you forget that I'm in charge here?

But Jenny, Melanie does have a point. I don't think you really want to return all those cans, do you? And the nursing staff really enjoys the convenience of the fountain pop machine.

Jenny

Well Sally, I guess that's not my call. If your mind is made up, I'll do without the cans...

But back to the snacks ordering, does Sam's Club even deliver? Right now Norman Foods delivers two days after I place my order, and they even unload the snacks for me in the back closet. Will Sam's Club do that for us?

Karley

And why is this the first time I've heard we will be using a snack vendor other than Norman Foods? Does Sam's Club have everything we need?

Melanie

First, ladies, let me remind all of you that we must do something different to save money. Sam's Club offers a great assortment of snacks at competitive prices. While they do not deliver, I know we will make up for that service in direct cost savings. The only snacks they do not provide are...

Jenny

What? They don't deliver? Well, you wouldn't expect me to drive over there once a month to shop for snacks, let alone drive them back to the center and unload them myself, do you?

Melanie

Jenny, please let me finish. And no, I expect you to do this every week, just like I order the medical supplies every week. This will keep our inventory to a minimum. Now, where was I... oh yes, to answer your question, Karley, the only items Sam's Club doesn't offer are Saltine and Graham Crackers. However, Sam's Club does have Goldfish Crackers and Zoo Animal Crackers that will serve as adequate alternatives. 
Jenny

Every week? Run to Sam's Club every week? You've got to be kidding me!

Sally

Now, now Jenny, this is just Melanie's idea. Nothing is set in stone as of yet. I still get to make the final decision.

Karley

We must have Graham Crackers. Dr. Manther prefers the Golden Honey Graham Crackers. He must eat at least three packs each time he does cases here.

Sally

I really think Dr. Manther would stop doing cases here if he didn't have his Graham Crackers. Dr. Manther's case volume accounts for $8 \%$ of our total cases. Melanie, you've got to figure this one out. We need his Golden Honey Graham Crackers

Melanie

Well, let's just recap. Currently, Sally thinks we are saving money with the new fountain pop machines, and I have a feeling we will save money switching snack distribution from Norman Foods to Sam's Club. I just have to run the numbers. We could also limit the amount of snacks we offer patients after their surgeries. I personally think they currently have too many different types of snacks from which to choose.

Karley

Melanie, the more I think about it, the more I just don't agree with these changes. We are an ASC, not a hospital. We want the patients to feel comfortable and at home, and I don't want to sacrifice their experience here. This is why we have a variety of snacks for them to choose from and all the different beverages. I understand you need to save money, but it shouldn't be at the expense of our patients. I also think we need to bring back the larger snack baskets in the post-operative waiting room so patients have more snacks from which to choose. It was a nice trial this past month; but I just think we are sacrificing patient satisfaction. We need larger snack baskets.

Melanie

Now just hold on for a second. You really think we are sacrificing patient care? I'm not entirely sold on the changes either, but at the hospital patients get a single package of Saltine Crackers and a cup of ice water for goodness sake. Here, they practically have a buffet of snacks and pop. I think it is ridiculous that we have to stock so many different types of pop, juice and food when we just don't have adequate storage space, not to mention the staff's time that goes into maintaining a "sufficient" stock of snacks.

Sally

I agree, Melanie. We do stock a wide variety of snacks here at the surgery center.

Melanie

Don't forget about the Medicare patients who just load up on the snacks in the post-operative waiting room. We've had multiple patients request a second basket of snacks, only to find their family members emptying the snacks into their purses! 
Jenny

Ladies, I just want to keep the customers happy. If they like their snacks, let them have 'em. They aren't that expensive, and I'm sick of dealing with complaining patients and family. Like I said, the front desk girls and I just don't have the time to waste on issues that could be avoided. And I definitely don't have the time to drive to Sam's Club to go shopping for the ASC every week.

Karley

Jenny, you're not the only one who's busy here. You should try a day with all those tonsillectomy patients who scream and cry for the duration of their stay. The physicians just keep pushing them through like they're doing oil changes, and I have to take care of all those whiney kids. Try my job for a day, and then you'll really know what hard work is.

Sally

Well, I don't think we are getting anywhere here. Hmmm... Martha, what do you think?

Martha

As I said before, I would leave good enough alone. I don't see the merit in all of these changes. Maybe we can just table this for six months.

Jenny

Wait a second! I forgot something. How did we forget that we are wasting half the fountain pop syrup? The pop syrup expires every three months, on average, and last month we threw away the majority of the Ginger Ale, Sprite and Coca Cola Zero. Karley and Melanie, you think we are saving money with the fountain pop when really we are wasting half of it.

Melanie

Jenny, I'll let you know what we are saving on the pop after I crunch the numbers.

Now, I forgot about something that's been bugging me. Jenny orders once per month but due to the lack of storage, I have to keep her food inventory on my medical supplies inventory shelves. There just isn't enough space for my products as it is! This is just another reason why weekly ordering through Sam's Club is such a fantastic idea. The more I think about it, the more I love it!

Jenny

Now Melanie, I'm tired of hearing about your limited inventory space. I'm trying to save money here, too! I know Karley puts the orders together, and I just fill out the purchase order, but ordering once per month saves us delivery charges. Norman Foods charges us $\$ 25$ if we don’t spend at least $\$ 300$ per order, so I assumed I should just buy once a month to save on delivery charges.

Karley

Well, I don't care where we purchase our snacks, but I do want to make sure we have Dr. Manther's Honey Graham Crackers and that we keep the fountain pop around. The fountain pop is much more convenient than all the cans we had to deal with, and it's cheaper! Even if we waste half of the syrup, we don't have to deal with the cans piling up and then returning those sticky empties. 
Sally

Well, after hearing all of your points, it sounds like there is still more money to be saved. I didn't realize we were wasting pop! And maybe there is a way that Jenny won't have to run to Sam's.

So Melanie, how do you see this panning out?

Melanie

Well, we have transitioned from Pepsi cans to Coca Cola fountain pop. Most of the staff prefer the fountain pop; however, half of the syrup expires before we consume it (see Exhibits IV and V).

Table IV: Pepsi Invoice: Month of March (One Month)

\begin{tabular}{|l|c|c|c|}
\hline \multicolumn{1}{|c|}{ Description of Pop } & Cases* & Cost per Case & Extended Purchase \\
\hline Pepsi & 2 & $\$ 11.63$ & $\$ 23.25$ \\
\hline Diet Pepsi & 3 & $\$ 11.63$ & $\$ 34.88$ \\
\hline Sierra Mist & 1 & $\$ 11.63$ & $\$ 11.63$ \\
\hline Diet Sierra Mist & 2 & $\$ 11.63$ & $\$ 23.26$ \\
\hline Mountain Dew & 1 & $\$ 11.63$ & $\$ 11.63$ \\
\hline Mug Root Beer & 3 & $\$ 11.63$ & $\$ 34.88$ \\
\hline Lipton Brisk & 2 & $\$ 14.59$ & $\$ 29.18$ \\
\hline Aquafina Water & 3 & $\$ 6.57$ & $\$ 19.71$ \\
\hline Delivery Fee & & $\$ 15.00$ \\
\hline *Pop = 12 Cans/Case; Aquafina Water = 24 Bottles/Case & \\
\hline
\end{tabular}

Table V: Coca Cola Invoice: Months of June, July and August (Three Months)

\begin{tabular}{|l|c|c|c|}
\hline \multicolumn{1}{|c|}{ Description of Pop } & Boxes of Syrup & Cost per Case & Extended Purchase \\
\hline Coca Cola Zero & 1 Small & $\$ 32.97$ & $\$ 32.97$ \\
\hline Seagrams Ginger Ale & 1 Small & $\$ 32.97$ & $\$ 32.97$ \\
\hline Powerade Mt. Blast & 1 Small & $\$ 32.97$ & $\$ 32.97$ \\
\hline Classic Coca Cola & 1 Large & $\$ 62.95$ & $\$ 62.95$ \\
\hline Diet Coke & 1 Large & $\$ 62.95$ & $\$ 62.95$ \\
\hline Sprite & 1 Large & $\$ 62.95$ & $\$ 62.95$ \\
\hline Carbon Dioxide Charge & & $\$ 16.95$ \\
\hline
\end{tabular}

We have a wide variety of snacks available for our patients in the family waiting room and the postoperation waiting area. While I purchase all the medical supplies in the facility, Karley lets Jenny know which snacks need to be ordered. Then, Jenny does the paperwork and places the purchase order.

We currently purchase our snacks from Norman Foods but could possibly realize additional savings if the snacks were purchased from Sam's Club. I have not preformed a cost analysis in regard to Norman Foods and Sam's Club, but I have gathered their pricing schedules for equivalent snacks (see Exhibit VI and VII). 
Table VI: Norman Foods: Average Monthly Consumption

\begin{tabular}{|l|c|c|c|}
\hline \multicolumn{1}{|c|}{ Table VI: } & Averman Foods: Average Monthly Consumption & Cost per Case \\
\hline 12 oz Cups $*$ Units Consumed & 1000 & 1000 & $\$ 23.29$ \\
\hline Apple Juice, 5.5 oz & 37 & 48 & $\$ 23.96$ \\
\hline Cheese \& Peanut Butter Crackers & 410 & 192 & $\$ 29.96$ \\
\hline Cocoa Mix & 16 & 36 & $\$ 17.92$ \\
\hline Creamer, Non-Dairy, 11 oz & 6 & 12 & $\$ 23.36$ \\
\hline Cranberry Juice, 5.5 oz & 52 & 48 & $\$ 9.58$ \\
\hline Goldfish Crackers & 215 & 24 & $\$ 20.29$ \\
\hline Graham Crackers & 318 & 550 & $\$ 10.87$ \\
\hline Kudo Bars & 125 & 36 & $\$ 16.00$ \\
\hline Lids, for 12 oz Cup & 700 & 500 & $\$ 28.44$ \\
\hline Mini-pretzels & 195 & 88 & $\$ 11.77$ \\
\hline Minute Maid Orange Juice, 6.75 oz & 70 & 40 & $\$ 8.97$ \\
\hline N'Joy Pure Cane Sugar, 18 oz & 3 & 8 & $\$ 21.81$ \\
\hline Nutri-Grain Cereal Bar, Fruit Filled & 205 & 48 & $\$ 10.49$ \\
\hline Oats N' Honey Cereal Bar & 325 & 30 & $\$ 54.39$ \\
\hline Peanut Butter, Skippy, 64 oz & 3 & 6 & $\$ 12.04$ \\
\hline Saltine Crackers & 242 & 500 & $\$ 27.00$ \\
\hline Sun Chips & 180 & 36 & $\$ 8.98$ \\
\hline Tea Bags & 80 & 44 & $\$ 9.18$ \\
\hline Zoo Animal Crackers & 445 & 36 & \\
\hline *Styrofoam Cup & & & \\
\hline
\end{tabular}

Table VII: Sam's Club: Average Monthly Consumption

\begin{tabular}{|l|c|c|c|}
\hline Snack Description & Average Units Consumed & Units per Case & Cost per Case \\
\hline 12 oz Cups* & 1000 & 160 & $\$ 11.48$ \\
\hline Apple Juice, 5.5 oz & 37 & 48 & $\$ 21.10$ \\
\hline Cheese \& Peanut Butter Crackers & 410 & 192 & $\$ 23.04$ \\
\hline Cocoa Mix & 16 & 36 & $\$ 4.32$ \\
\hline Creamer, Coffee-Mate 16 oz & 6 & 8 & $\$ 9.88$ \\
\hline Cranberry Juice, 5.5 oz & 52 & 48 & $\$ 22.98$ \\
\hline Goldfish Crackers & 336 & 24 & N/A \\
\hline Graham Crackers & 0 & N/A & $\$ 9.82$ \\
\hline Kudo Bars & 125 & 75 & $\$ 3.00$ \\
\hline Lids, for 12 oz Cup & 700 & 88 & $\$ 22.88$ \\
\hline Mini-pretzels & 316 & 40 & $\$ 9.49$ \\
\hline Minute Maid Orange Juice, 6.75 oz & 70 & 8 & $\$ 9.98$ \\
\hline N'Joy Pure Cane Sugar, 22 oz & 2 & 48 & $\$ 12.47$ \\
\hline Nutri-Grain Cereal Bar, Fruit Filled & 205 & 30 & $\$ 7.20$ \\
\hline Oats N' Honey Cereal Bar & 325 & 4 & $\$ 30.64$ \\
\hline Peanut Butter, Jiff, $80 \mathrm{oz}$ & 2 & $\mathrm{~N} / \mathrm{A}$ & $\mathrm{N} / \mathrm{A}$ \\
\hline Saltine Crackers & 0 & 36 & $\$ 17.28$ \\
\hline Sun Chips & 180 & 44 & $\$ 8.28$ \\
\hline Tea Bags & 80 & 36 & $\$ 6.84$ \\
\hline Zoo Animal Crackers & 660 & & \\
\hline *Eco-Friendly Cup & & & \\
\hline
\end{tabular}

Melanie

I would be more than happy to analyze the data and let you all know our best course of action.

Sally

This sounds like a good summary of where we stand, Melanie. Why don't you prepare the numbers and a recommendation, and we will all meet again next Tuesday at the same time to discuss our options. 


\section{REQUIREMENTS}

Given the dynamics of the pop and snacks discussion, Sally has hired you to assist Melanie in finalizing the snacks and pop purchasing decision.

1. Identify and analyze the ASC's snacks and pop purchasing options.

2. Prepare Melanie's follow-up presentation for next week's meeting.

\section{TEACHING NOTE}

Faculty desiring a comprehensive teaching note should contact Timothy Moffit at timothy.moffit@kzoo.edu.

\section{AUTHORS' INFORMATION}

Timothy Moffit, Kalamazoo College, Department of Economics \& Business, 1200 Academy Street, Kalamazoo, MI 49006, USA. E-mail: Timothy.Moffit@kzoo.edu (corresponding author)

Michelle Gigowski, Kalamazoo, MI 49006, USA. E-mail: Michelle.R.Gigowski@gmail.com 


\section{NOTES}

